\title{
Exhortation and sympathy in the Paul's Cross Jeremiads
}

Article

Accepted Version

Morrissey, M. (2017) Exhortation and sympathy in the Paul's Cross Jeremiads. English Studies, 98 (7). pp. 661-674. ISSN 1744-4217 doi:

https://doi.org/10.1080/0013838X.2017.1339994 Available at https://centaur.reading.ac.uk/69249/

It is advisable to refer to the publisher's version if you intend to cite from the work. See Guidance on citing.

To link to this article DOI: http://dx.doi.org/10.1080/0013838X.2017.1339994

Publisher: Taylor \& Francis

All outputs in CentAUR are protected by Intellectual Property Rights law, including copyright law. Copyright and IPR is retained by the creators or other copyright holders. Terms and conditions for use of this material are defined in the End User Agreement.

\section{www.reading.ac.uk/centaur}

\section{CentAUR}

Central Archive at the University of Reading

Reading's research outputs online 


\section{Exhortation and sympathy in the Paul's Cross Jeremiads}

This article considers affective rhetoric by examining the idea of exhortation. Appealing to the emotions in sacred rhetoric was not a strategy opposed to reasoned argument (as it often figures in secular rhetoric): rather, feelings of love for God and sympathy for one's fellow Christians were among the virtues that preachers sought to rouse in their hearers. Nor were the emotions and the reason rigidly separated in homiletic theories; the preacher persuaded through argument, through rhetorical figures and through the vehemence that his own spiritual conviction created. These links between argument, example and affection in persuasion are best demonstrated in the exhortation, which uses all the resources that the preacher had at his disposal to move his hearers towards godliness. One of the most significant means of persuasion was for the preacher to create a sympathetic bond between himself and the hearers. He addressed them as thinking and feeling members of a Church in which they all shared an interest. This aspect of affective rhetoric is best seen in the Paul's Cross Jeremiads, a sermon genre particularly associated with exhortation and characterised by vehement appeals to a sense of common purpose.

Keywords: exhortation; Jeremiads; sympathy; reason; affections.

Jeremiads are not always read primarily as sermons of exhortation. The genre is named rather from their biblical texts: quotations from the prophetic books of the Old Testament (most particularly Jeremiah and his account of the Babylonian exile) become the basis for impassioned warnings that God's punishment for sins threatens the wellbeing of the community. Although the emotional force and rhetoric vehemence of the genre is uncontested, the emotions associated with the Jeremiad are usually negative ones: fear of divine punishment and a self-righteous belief that only the presence of a godly 'saving remnant' preserved the Church and kingdom from disaster. The sermons have been interpreted as rhetorically divisive: In New England, the failures of the younger generation were contrasted with the heroic virtue of their migrant parents. ${ }^{1}$ Paul's Cross Jeremiads have been read for clues to the divisions between the godly and their neighbours that prompted the puritan migration. ${ }^{2}$ In what follows, I use a closer

\footnotetext{
${ }^{1}$ For an account of the debate begun by Perry Miller in The New England Mind, 463-491, see Bercovitch, The American Jeremiad (which takes a more positive view of the Jeremiad), Foster, The Long Argument, and Bremer, 'To Live Exemplary Lives'.

2 McGiffert, 'God's Controversy with Jacobean England'; Collinson, 'The Cohabitation of the Faithful with the Unfaithful'.
} 
examination of the rhetorical means for affective rhetoric to show the pastoral purposes of the Jeremiads more clearly. I read them as essentially sermons of exhortation. In exhortation, preachers were instructed to use all the rhetorical means at their disposal to change their hearers' hearts and minds: they provided arguments to show that godliness was necessary and achievable; they used a rhetorically vehement style to provoke an emotional response; and they spoke with a sincerity that communicated their belief in what they said. In the exhortations that characterise Paul's Cross Jeremiads, we can find a re-affirmation of the centripetal force that the idea of the Church sustained in early modern Protestantism. ${ }^{3}$ Preachers sought to excite a sense of fellow-feeling in their hearers for the other members of the Church, at home and abroad. For this reason, sympathy is a key element in the effective strategy used in these sermons. Paul's Cross Jeremiads were designed to provoke not only personal repentance, but also communal reform of civic and religious institutions.

The Jeremiad had no new doctrine to proclaim: its function was merely to convince the hearers to change their ways. As a genre, it therefore provides ideal material for studying methods of reaching the emotions in early modern preaching. We know that this aspect of preaching was considered vital, and scholars have not neglected it. But our consideration of how preachers attempted an emotional change in their hearers has often been limited to an examination of 'style': choice of rhetorical genus (which determined diction, and use of figures and tropes), ${ }^{4}$ pronunciatio (tone of voice) and gesture. Arnold Hunt's ground-breaking study of The art of hearing, for example, expertly refutes the idea that puritan sermons were 'austerely logical and unemotional'. But his discussion of affective preaching emphasises tone of voice and gesture as the

\footnotetext{
${ }^{3}$ Morrissey, 'The Paul's Cross Jeremiad and Other Sermons of Exhortation'.

4 Peter Auksi traces the origins of the 'Christian plain style', in which didactic seriousness and conviction create persuasive force: Christian plain style, esp. pp. 266-303; Debora K. Shuger has demonstated that a 'Christian grand style' that combined an unadorned styl with vehemence is vital to our understanding of early modern preaching rhetoric, Catholic and Reformed: Sacred rhetoric, esp. pp. 30, 64-100.
} 
preacher's means to move his hearers emotionally. ${ }^{5}$ The earlier part of the composition process (inventio, the choice of scriptural prooftexts and commonplaces of argument) has been neglected as a basis for affective rhetoric. But contemporary preaching manuals discuss all elements of persuasion as vital for this most important task.

Increasingly, sixteenth and seventeenth-century preaching theories use the term 'exhortation' to cover the varied means necessary to create the 'moving' rhetoric that Protestant preaching demanded. Examples of exhortation were said to be common in Scripture and preachers often noted when the text of their sermon was an exhortation. ${ }^{6}$ But the Classical sources on which much Renaissance rhetoric was based had little to say about exhortation: it is not discussed in the Rhetorica ad Herennium or Cicero's De Inventione. In De Oratore, Cicero notes that in advisory speeches on public affairs 'the greatest part of a speech must occasionally be directed to arousing the emotions of the audience, by means of exhortation or of some form of reminder, to either hope or fear or desire or ambition'. In Topica, he does not define exhortation but mentions that exhortations 'to defend the state, and to seek fame and glory' come 'under the heading of arousing emotions'. ${ }^{7}$ Early modern secular rhetorics gives exhortation more attention, but they are less decided that exhortation belongs in the category of affective rhetorical strategies. For J.C. Scaliger, exhortation is a form of deliberatio, a figure of argument. Henry Peacham lists commonplaces of argument best used in exhortation, including 'the prayse and expectation of men, hope of victory, hope of rewarde, hope of renowne, feare of shame, examples of all tymes'. Although both writers agree that exhortation

\footnotetext{
${ }^{5}$ Hunt, The art of hearing: 82, see also 10-11, 62-3, 81-94. On performative styles in the pulpit and affective oratory, see also Francis Bremer and Ellen Rydell, 'Performance Art? Puritans in the pulpit'. ${ }^{6}$ Hyperius of Marburg writes that 'the holy Scriptures doe abounde with precepts and exhortations': De formandis concionibus sacris (1553), trans. The practis of preaching, f. 18v; Charles Richardson remarks that his text is primarily meant for exhortation: A sermon against oppression and fraudulent dealing, 2. So too does William Whately, A caveat for the covetous, 2

${ }^{7}$ Quintilian merely mentions exhortation: Institutio Oratoria, IX. ii. 103, LCL 127, 94-5; Cicero, De Oratore, II.1xxxii.337, LCL, 348, 452-5; Topica, XXII.86, LCL, 386, 448-9.
} 
includes appeals to the emotions, they also treat it as fundamentally argumentative: it is used to promote or dissuade from an action and gives reasons and arguments for doing so. ${ }^{8}$

The significance of exhortation to early modern sacred rhetoric is most probably due to the influence of Erasmus. Erasmus places most sermons in the suasive or deliberative genre, but he insists that he will also deal with exhortation, consolation and rebuke (citing St Paul, 1 Tim. 3:16). ${ }^{9}$ Nonetheless, exhortation continued to present problems of definition. Erasmus did not always treat it as a separate genera of sermon, and describes it rather as 'a part of the suasorial type rather than a different one', and he emphatically allied it to the moving of the emotions, as Cicero had done: 'someone who is persuading is teaching through arguments, someone that is exhorting is stimulating through the emotions'. ${ }^{10}$ Writing fifty years later, William Perkins brings exhortation back to the realm of argument by placig it with the 'instructive use' of the sermon's doctrine 'whereby doctrine is applied to frame a man to live well in the family, common-wealth, and Church'. ${ }^{11}$ Richard Bernard, whose advice fits closest to the practice of Paul's Cross preachers, had similar difficulty finding an exact place for exhortation. He lists four possible uses for the sermon's doctrine: confutation, instruction, reprehension and consolation. Exhortation and dehortation, Bernard writes, are 'appendices to these'. Preaching theorist were unsure, therefore, if exhortation was to be effected by an emotionally vehement style or by reasoned argument: it therefore

\footnotetext{
${ }^{8}$ Scaliger, Poetices libri septem, III. cv, 398-9; Henry Peacham, The Garden of Eloquence, 77-8. ${ }^{9}$ Erasmus, Ecclesiastes, CWE, 68, 546. On the extraordinary influence of this work, see McGinness' introduction to this edition, Robert G. Kleinhans, 'Ecclesiastes sive de Ratione Concionandi', in Essays on the Works of Erasmus, 253-266; John O'Malley, 'Erasmus and the History of Sacred Rhetoric', Religious culture in the sixteenth century (Hampshire: Variorum, 1993), ch. VII.

10 Erasmus, Ecclesiastes, CWE, 68, 567. Nonetheless, Erasmus goes on to detail commonplaces of argument and what other preaching rhetorics refer to as 'motives' for use in exhortation: 567-71.

${ }^{11}$ Perkins, The Arte of Prophecying, 124.
} 
cut across the faultline between reason and the emotions that shaped Classical and Renaissance secular rhetoric.

Because exhortation belonged exclusively neither to agument nor style, the concept could expand until it effectively encorporated most of the persuasive function of the sermon. Richard Bernard's advice demonstrates the many tasks included in crafting a successful exhortation: the preacher must consider the spiritual state of his hearers (whether they need to be brought to repentance or encouraged by consolation) and 'the motives to perswade and draw them to the practise, and to continue therein'. He needs to 'move and gaine the affections' of his hearers, so that they are motivated to follow the advice he offers, and he must present them with the means to do so, 'from the easines, from the hope of Gods assistance promised to such as laboure to doe well ... and so forth'. ${ }^{12}$ Bernard's advice is typical of other preaching handbooks, which describe the exhortation as the rhetorical means by which the hearers are persuaded to adopt the advice advanced by the preacher, or in contemporary terminology by which the 'uses' of the sermon's doctrine are 'applied' to the hearers. These rhetorical means are tailored to the circumstances of the hearers, and were build on arguments and evidence (often examples from Scripture or history). ${ }^{13}$ Hyperius of Marburg's popular De formandis concionibus sacris encouraged preachers to use 'the craft or cunning of moving of affections' through the 'the engins of art and grace in speaking', but he also wrote of the 'furniture of arguments' that the preachers need to 'move and stirre up the myndes of the hearers'. ${ }^{14}$ Affective oratory was only one strategy for exhortation, and this vital task required all the rhetorical resources available. Richard Bernard advises

\footnotetext{
12 Bernard, The faithful shepheard, 294-306.

${ }^{13}$ For similar lists of commonplaces of argument, see Hemmingsen, The Preacher, or Method of Preaching, ff. 53v-54r; Ursinus, Methodus formandi concionem, in Keckermann, Rhetoricae Ecclesiasticae (1606), 149-50; Sutcliffe, De recte studii theologici ratione, 86-7. Clarke, Oratoria Sacra, 487.

${ }^{14}$ Hyperius, trans. Ludham, The practis of preaching, f. 43r.
} 
preachers to use 'the figures of Rhetorick', and he lists eight in particular with 'power of attraction, \& pulling to them the affections of the hearers', but these are given relatively little space compared to the delineation of 'means to and motives for' exhortation that can be used. ${ }^{15}$

If exhortation functioned both by providing arguments and through literary craft, then it raises questions about the relationship these preaching theorists posited between the emotions and the other parts of the 'tripartite soul' (reason and will). Moving the emotions cannot be merely matter of 'style' (in figures of speech, voice or gesture), as previous discussions of affective rhetoric have suggested. If the preacher uses arguments in exhortation, it must be because the hearers' reason must also be addressed. Emotional engagement with a sermon is not, therefore, divorced from intellectual engagement with it. We must examine the links between reason and feeling to see why both are targeted by the preacher in exhortation.

'Passion' is a hard term for us to translate, being sometimes used as a synonym for 'affection' while not quite equating to our term 'emotion'. Where the word 'passion' indicates something acted on, 'affection' indicates an active force, something that moves and makes an impression. The difficulty of offering a single word to encompass the different notions delineated by the terms 'passions' and 'affections' is explained by Susan James:

Passions, then, are generally understood to be thoughts or states of the soul which represent things as good or evil for us, and are therefore seen as objects of inclination or aversion. ... The passivity of the passions and the stirrings of the perturbations [or affections] may initially seem at odds with one another: the one at rest, the other in motion; the one inactive, the other driving. But these two descriptions are brought together in an understanding of the passions as forces that are at once extremely powerful and actually or potentially beyond our control. They perturb the economy of soul and body in ways that we are sometimes unable to prevent. ${ }^{16}$

\footnotetext{
15 Bernard, The Faithfull Shepheard, 302

16 James, Passion and action, 4, 11. On the difficulty of finding modern equivalents for these terms, see also Dixon, From passions to emotions, 13-15.
} 
The disturbing quality is particularly acute in the case of those passions that are primarily reactions to sense stimuli (the sensory appetite): we can feel powerful responses of attraction or repulsion to things we encounter in the world, and the power of that response can cause us to respond without rational consideration. Conventionally, secular oratory considers passionate rhetoric as a technique that allows the speaker to by-pass the hearers' reason. In Aristotle's Rhetoric persuasion by passionate rhetoric is done by language that provokes passions in the hearers; persuasion by argument is managed by presenting convincing arguments. ${ }^{17}$ This is one of the reasons why secular rhetoric considered appeals to the emotions as potentially morally suspect. ${ }^{18}$

But the starting place for most accounts of the emotions in sacred rhetoric was St Augustine. ${ }^{19}$ In The City of God, IX.4 and 5, Augustine takes issue with the Aristotelian and Stoic accounts of the emotions. In particular, he rejected the Stoic teaching that the wise man reached a state of apatheia, in which he felt no passions:

There is no need at the moment to point out at length and in detail what lessons divine Scripture, which is our store of Christian learning, teaches concerning these passions. The point is that Scripture subordinates the higher mind itself to God, to be governed and succoured by him, and puts the passions into keeping of the mind, to be so regulated and restrained as to be converted into servants of righteousness. Consequently, in our system we do not so much ask whether a religious mind will become angry, but rather what should make it angry, nor whether it will be sad, but what should make it sad, nor whether it will be afraid, but what should make it afraid. ${ }^{20}$

\footnotetext{
17 Vickers, In defence of rhetoric, 19-20. Aristitle, Rhetoric, 1356a, LCL, 193. 16-7.

18 Skinner, Reason and rhetoric in the philosophy of Hobbes, 120-9;. Shuger, Sacred rhetoric, pp. 118 20.

${ }^{19}$ On Augustine's influence on early modern preaching theory generally, see Kneidel, 'Arts Praedicandi: Theories and Practice', 3-20, esp. 3-9.

${ }^{20}$ City of God, IX.5, LCL 414, 166-7. For a fuller discussion of Augustine and Aquinas's theories of the passions and affections, the bedrock of almost all sixteenth and seventeenth-century discussions of the subject, see Dixon, From passions to emotions, . 26-61.
} 
The passions are not evil, but they are unruly; it is the object to which they tend that determines their moral value. ${ }^{21}$ This insight became central to Thomas Aquinas' highly influential account of emotions in The Treatise of the Passions. Directed towards the right object, the passions and affections are as much a part of human flourishing as the reason and the will.

Debora Shuger has described the ways in which the priority given to feelings like love and faith unsettles the Classical dichotomy between reason and passions:

The principal factor in the legitimation of affect, and hence of rhetoric, was Augustine's sweeping and massively influential rejection in The City of God of the classical intellectualist tradition with its hierarchical faculty psychology in favour of a more unified picture of mental activity, one in which feeling, willing, and living become tightly intertwined. The emotions, Augustine thus argued "are all essentially acts of the will", for as the will is attracted or repelled by different objects, "so it changes and turns into feelings of various kinds." Volition, subjectively experienced, is emotion, and Augustine uses the term "love" to denote the orientation of the self toward the desired object. Affectivity, instead of being an irrational perturbation, thus moves into the center of spiritual experience. $^{22}$

Willing and feeling are closely linked, therefore: volition is emotional, and affectivity is not irrational. Shuger's insight into affectivity in sacred rhetoric shows that the early modern period had different models of the relationship between the will (the function that sets mind and body on a course of action), the affections (or passions) and the intellect. Indeed, many writers offered understandings of the relationship between these faculties that were inconsistent with each other, or with the sources on which they drew. There were, however, some assumptions undoubted shared by most thinkers that can help us understand the persuasive force proposed for exhortation and why they combine argument with vehement style and appeals to personal conviction.

\footnotetext{
${ }^{21}$ For a detailed account of the ways that John Donne used this Augustinian idea in his preaching, and in his thinking about the role of emotion in human responses to the divine, see Katrin Ettenhuber, "Tears of passion" and "Inordinate lamentation", 201-16.

22. Shuger, 'The philosophical foundations of sacred rhetoric', 47-64, pp. 52; see Sacred rhetoric, pp. 149-53, for an earlier discussion of this issue.
} 
First among those assumptions was that human beings were a composite of body and soul: the soul was not merely the 'ghost in the machine' but was one of two intrinsically linked elements in a single, divine-ordained and perfectible creature. The body affected the soul, through the information received by the senses, and the soul affected the body, conditioning it to respond to perceived goods and threats in appropriate ways. Body and soul were ordained by God for perfect happiness, and they are therefore naturally disposed towards goodness and God. The damage wrought by original and by personal sins makes this natural inclination harder to effect: the intellect misunderstands what is good; the affections and passions are moved towards things that are not good, or moved inordinately towards short-term goods; and the will is unable to function in co-ordination with reason. As a result, we follow the promptings of our 'baser' or 'disordered' desires. This was not always necessarily the case, however. The emotions could be directed toward God and what is good, as St. Augustine had insisted: the preacher's task was partly to redirect the troublesome emotions.

The second assumption that finds its way into early modern thinking on exhortation in sacred rhetoric relates to the troublesome distinctions between the phenomena that we classify as emotions. The period was not short on classifications of the passions, ${ }^{23}$ but there was no consensus about what distinguished the passions from the affections, or if both terms could be used to describe the same movements of the soul. Clearly, many passions were responses to the bodily senses: we see or hear something that provokes the feeling of fear, or we taste or touch something that provokes a feeling of desire (the wish to acquire the thing). But others were not: they were provoked by more abstract things, like thoughts or beliefs. Feelings of loyalty

\footnotetext{
${ }^{23}$ James, Passion and action, 4-8. James alerts us to the fact that these writers 'inherit and elaborate a long and palimpsestic tradtion of attempts to provide a comprehensive classification of key emotions in terms of which all variants can be analysed; and while they do not arrive at any final consensus, they work with and sustain the view that certain passions are central' (4-5).
} 
were not merely responses to sense stimuli; feelings of joy could be provoked by nonphysical goods, such as the contemplation of God. These were sometimes called 'affections of the will', to distinguish them from passions derived from the sensitive appetites. Thomas Wright explains this as follows:

And to be briefe in this poynt, I think it cannot be doubted upon, but that there are some affections in the highest and chiefest part of the soule, not unlike to the Passions of the Minde: for to God the Scriptures ascribe love, hate, ire, zeale, who cannot be subject to any sensitive operations: And therefore, as in him they are perfections, and we are commaunded, and may imitate him in them, there is no reason why they should be denyed unto us, in such sort as they be perfite, and that is principally in the Will. ${ }^{24}$

For Thomas Aquinas, the affections of intellect and senses were not mutual exclusive.

Nicholas Lombardo argues that Aquinas saw 'the will's loves, desires, and joys, as well as its hates, aversions, and sorrows, can spill over into the passions of the sense appetite by a kind of overflow, because "it is not possible for the will to be moved intensely towards something without exciting some passion in the sense appetite".'25

It is important to realise that the 'tripartite' soul on which early modern preaching theorists based their models of persuasion (and therefore exhortation) was one in which the different faculties could influence each other. Emotional responses did not necessarily by-pass the reason, and some emotions were 'affections of the will', laudable desires for God and the good. In the words of William Fenner:

These acts of loving, fearing, \&c commonly called by the name of Affections (I speake with submission to better Judgements) are onely the motions of the will, by which it goeth forth to the embracing of its object which is good: which considered in the general nature is loved, considred as in the fruition is delighted in; considered in the future as attainable, if with ease, is desired; if with difficulty, is hoped for; if the will or these Affections be fixed on their proper object, there is no danger in the excesse; God cannot be loved, or feared, \&c over-much; the only danger in them, is either in misplacing upon a wrong object, or their loose adhering to the right. 26

\footnotetext{
24 Wright, The passions of the minde in generall, 30-1. See also Edward Reynolds. A treatise of the passions, 36-9. Edwards describes three categories of passions in man: mental, sensitive and rational. 25 Nicholas E. Lombardo O.P., The Logic of Desire, 89-90.

${ }^{26}$ Fenner, A treatise of the affections, sig. $\llbracket 2 \mathrm{v}$.
} 
These links between the reason, the emotions and the will meant that the preacher had a variety of routes by which he could reach his hearers' thoughts and feelings. His object was not merely to gain their theoretical or intellectual assent that what he said was true; he also wanted to prompt his hearers to take up and act on the words he spoke.

Bartholomew Keckermann writes that persuasion had two elements: the first is to teach, and the second is to move 'the soul or the affections' ${ }^{27}$ And for that, the preacher did not try to by-pass reason, but to provoke a 'motion of the will' in the hearer; this would make the hearer desire those things about which the preacher spoke. Debora Shuger explains:

The sacred rhetorics (and, in general, Augustinian Christianity) set affective inwardness over dispassionate intellection. Yet - and this is the crucial point they do so in a way that links rather than opposes emotion and reason. That is, they do not treat rhetoric's power to move the heart and will as separate, or even separable, from the procedures of rational inquiry, as though rhetoric concerned the pursuit of the Good, while philosophy alone directed the search for Truth. Rather, these texts typically insist on the ineluctable 'interwovenness' of cognitive and emotional experience. ... Emotion is therefore bound up with argument; the orator moves by giving reasons. 28

Moving and persuading required strong arguments and a convincing style. That is why exhortation sat occupied so much space in early modern English preaching theories.

But there was another means by which the hearers could be moved, and it related to the particular function of preaching as an exercise that involved three parties, as Lancelot Andrewes put it, 'God, 'the Preacher, and the Hearer'. ${ }^{29}$ The preacher had to communicate his own conviction of the truth of what he said. According to Richard Bernard, first among the conditions necessary to 'move and gaine the affections, and the hearers to a love and desire to do the duty' is this:

let him bee moved in himselfe with compassion towards them, with love and joy in their spirituall welfare, and with sorrow for their sinnes, and feare of their damnation. ${ }^{30}$

27 Keckermann, Rhetoricae Ecclesiasticae, 26.

28 Shuger, 'The philosophical foundations of sacred rhetoric', 54.

29 Andrewes, XCVI Sermons, (1629), 130 (2nd pag.).

30 Bernard, The faithful shepheard, 299. 
In the same way, Hyperius of Marburg argues that:

Before all thinges, it is very necessary that hee which speaketh, doe conceyve such lyke affections in his mynde, and rayse them upp in himselfe, yea, and (after a sorte) shewe them forth to be seene unto others, as hee coveteth to bee translated into the myndes of his auditors. For hee that both in wordes, voyce, countenaunce and apte gesture, declareth himselfe to lamente and bee sory either for the perill or some, or for the common misery of all men, hee alone seemeth forthwyth to provouke the residewe to pitie and compassion. ${ }^{31}$

The proof-text quoted on this topic was usually 2 Cor. 2:4, Paul's boast that he spoken not with 'the enticing words of man's wisdom', but 'in the demonstration of the spirit and of power'. William Perkins, offers most insight into what the 'demonstration of the spirit' required of preachers was, and how it gave persuasive force to a sermon. In the first of his two treatises Of the Calling of the Ministerie, he explains what the 'demonstration of the spirit' means by insisting that the preacher is an interpreter and $a$ witness to Scripture:

Beside a bare publication of this justification, he must (as Paul did) witnesse and testifie it to the conscience of the sinner, that it is as certainly true, as God is true, For as a witnesse in doubtfull cases is called, that by his testimonie he may cleere the truth, so when the consciences of poore sinners are wavering and doubtfull what to beleeve, when they doubt of this righteousnesse, then is a true minister as a faithful witnesse of God to averre and testifie the truth, from his own conscience, knowledge and feeling of the infallible certaintie of Gods promises unto the doubtfull and distressed conscience of the sinner. 32

The preacher communicates his own belief in the truth of what he says through every element of his sermon, through his knowledge and his 'feeling of the infallible certaintie of Gods promises'. Like Perkins, John Wilkins uses 1 Corinthians 2.4 to place the persuasive force of the sermon in the preacher's ability to communicate personal belief:

It must be affectionate and cordiall, as proceeding from the heart, and an experimentall acquaintance with those truths which we deliver. Quod procedit è corde redit in cor: 'Tis a hard matter to affect others, with what wee are not first affected our selves. Praecipuum ad persuadendum est amare quod suades, Amanti pectus ipsum suggerit orationis ardorem. 'Tis said of John the Baptist that

${ }^{31}$ Hyperius, trans. Ludham, The practis of preaching, f. $43 \mathrm{r}$.

32 Perkins, Of the calling of the ministerie, 435. 
he was a burning and a shining light. Ardere prius est, Lucere posterius; Ardor mentius est, lux doctrinae. This is to speake in the evidence and demonstration of the spirit and of power. ${ }^{33}$

Among the most persuasive strategies available to the preacher, therefore, was the communication of conviction. The most effective means of 'moving' an audience for the preacher was to evoke sympathy in them: that they would share his feelings of faith in God, and fear of God, when he spoke of them.

We have, then, a complex model for exhortation in sacred rhetoric, where the preacher moves his hearers by appeals to their rational functions (providing reasons for them to adopt the advice he offers), but also by creating an affective bond between himself and them through 'the demonstration of the spirit'. If he is to move their affections to a love of God and neighbour, he must communicate those emotions in himself to them. He must help them to share the feelings of faith and trust in God, and pity and love towards others, which he should feel in himself as he preaches. The emotion to be stirred up through this demonstration of the spirit is a kind of sympathy: feeling along with the preacher, and feeling what he feels. That affective bond, between preachers and hearers and between all fellow-members of God's church, was a vital element in contemporary thinking about the nature of the Church. Its influence on New England has been traced by Abram C. Van Engen, but he places its origins among the godly ministers who preached Jeremiads at Paul's Cross:

The same principle that operated in physical, civil, and marital 'bodies' also worked its way into Puritan conceptions of the church, the Body of Christ. For the Puritans, this Pauline metaphor often referred to vocations: the hand did not serve the same needs as the foot, but each person, each vocation, worked together to serve the needs of the whole. Yet Christ's body also contained another important quality: it communicated one affection, via sympathy, to every member. ... For many Puritans, sympathizing with the church was thus seen as a natural result of joining it. ${ }^{34}$

\footnotetext{
${ }^{33}$ Wilkins, Ecclesiastes (1646), 73-4. Wilkins is quoting Erasmus here, who writes that 'the most important thing for persuasion, then, is to love what you are urging; the heart itself supplies ardour of speech to the lover', and uses the example of John the Baptist as a 'burning light': Erasmus, Ecclesiastes, CWE 67, 299.

${ }^{34}$ Van Engen, Sympathetic Puritans, 41-2.
} 
An examination of the Paul's Cross Jeremiads does indeed show that affective rhetoric was used as part of a complex system of exhortation, and was designed to provoke feelings of sympathy with fellow members of the church, in England and abroad. Obviously, the confessional differences of seventeenth-century Europe, particularly on the eve of the civil war, meant that expressions of sympathy with European protestants were often coupled with vehement statements of separation from the evils of Popery. Sympathy was only extended so far. ${ }^{35}$

One of the most characteristic aspects of the Jeremiads, among all the early modern English sermons that include an exhortation, is the way that the preacher directs his address: this is not to an individual, but to a group. London, or England, are encouraged to be more godly. Characteristic of many of these exhortations is an insistent use of the first person plural. Even when separating his hearers into social groups (magistrates, ministers, and householders), the preacher encourages all to play their part in a collective campaign against sin. They must recognise their common purpose, because God will punish the whole community if it fails to work together to amend its faults. In England summons Thomas Sutton makes an appeal to all 'that loves our Nation' as well as addressing magistrates, ministers and judges in turn to a collective effort to extirpate sin and forestall punishment:

Let it then bee our joint and greatest care, to empty our houses, to cleanse our streets, to weede the cockle and darnell out of this Land, that God may bee pleased long and long, to continue his true Religion, our peerelesse King, \& this little Kingdome, in peace and happinesse. Remember what I say, and I say it againe: Let it be your care (Right Honorable) to strike at the roote of sinne in the Citie: Let our reverend judges strike at the roote of sin in the Courts, on their Benches, in their Circuites: Let my Brethren of the Ministerie, strike at the root of sin in their charges: Let every man that cares for Sion, that loves our Nation, that favours Religion, that wisheth the glorie of our Lord to be immortall, that hath a true English and a Christian heart, fling one stone at the face, make one wound in the fore-head of $\sin .^{36}$

\footnotetext{
35 The ways in which sympathy incorporated members within the church but also created affective divisions with those not in the church is described very effectively by Van Engen.

36 Sutton, 'England's Summons', 64-5.
} 
In London's New-yeeres gift, Thomas Jackson told his hearers that the text on which he spoke illustrated the 'most waighty charge' that God placed 'upon Magistrates, Ministers, and all the people of God' for the removal of 'whatsoever person of thing, which doe any way hinder or hurt the fruitfulnesse and prosperity of his Church'. 37 Even Thomas Barnes, whose Wisemans forecast tells his hearers that God will give notice of his plagues for the benefit of the godly, does not diminish the importance of the corporate life of the Church. Among the sins whose prevalence indicates impending judgement is 'cruell and hard dealing with the Children of God', as well as 'want of compassion, and unreadines to help their brethren in affliction', and sympathy for fellow members of the Church:

A great many of us are much unlike the members of Christ. They are wont to take to heart, the afflictions of the Church, and to mourne with those that mourne. We doe not so. There is great need both of words, and of teares, to expresse our griefe for the losses, and crosses which the mysticall body of the Church hath sustained, since the troubles began in the Belgian-Countries, yet so farre are we from teares, that we seldome have thoughts, seldomer words (except it be for fashion, and noveltie) about the breaches of Sion, about the troubles of our brethren, to show that we doe Sympathize, and condole them. ${ }^{38}$

These sermons combine all the means of vehement persuasion available to the preaching, offering 'means' and 'motives', as the preaching theorists suggest, with 'the engins of art and grace in speaking' and the figures associated with affective rhetoric. Thomas Jackson's exhortation to London is described in the text (and marginal note) as a 'Lamentation':

Alas, alas, that we have long hunted Sathan and sinne, and pursued them with full crie, and behold, you suffer them to harbour, and to burrogh in your bosoms: Alas, alas, that God hath hunted them by Pestilence, Famine, and manifold dangers, which wee have narrowly escaped, and yet you will not suffer them to be taken: indeed, you spit at the mention of the divell, and defie that foule thing, in the meanetime, the sinnes of Atheisme, Idolatry, Blasphemy, Contempt of Gods Worship, Prophanation of Gods Sabboths, Murther, Whoredome, Drunkennesse,

\footnotetext{
37 Jackson, London's New-yeeres gift, f. 1v.

${ }^{38}$ Barnes, The wise-mans forecast against the evill time, 52-3.
} 
Pryde, Covetousnesse, Perjurie, \&c did never more abound, and there is the Divell: Oh, that wee could see an end of these things, before there be an end of all things: yea, let me end my Lamentation with a Prophecie; If these things be not taken away, by Word, or Sword, or both; he that hath exalted London to heaven, will bring her downe to hell. ${ }^{39}$

This emotional style was sometimes presented as a mirroring of the exhortatory nature of the biblical text itself: God exhorted the Israelites through the prophet's words, presented motives and emotional appeals to the people just as the preacher did in taking those words for his sermon. Thomas Sutton explains that the preacher's words in his text threaten that 'every one shall be cut off' because 'by these Rhetorical amplifications, he might more feelingly affect and move the hearts of the Israelites, both with some touch and feeling of their owne sins, and his punishments.' And adopting the voice of the prophet in his text, he brings the message of God to the Israelites home to his London hearers:

You cannot chuse but know, how carefully I have sollicited, how friendly I have admonished, how powerfully I have exhorted, how sincerely I have instructed you in matters concerning God and your own peace, but my words have perished in the aire, I have spent my strength upon you in vaine, and for nothing. ${ }^{40}$

The rhetorical charge of these prophetic quotations is unmistakable. And like the Old Testament prophecies, these exhortations were addressed to the whole people, to promote a common purpose by encouraging sympathy: with fellow-members of the church and the community, and with members of the Church in other communities. This explains why so many of these exhortations make examples of religious wars then current, or churches already lost to Christianity. Thomas Jackson reminds his hearers that the seven churches of Asia mentioned in Revelations 2-3 are gone: God 'gave them over unto Turkish slavery' ${ }^{41}$ Roger Lee blames the loss of Constantinople on Christian

\footnotetext{
39 Jackson, London's New-yeeres gift, ff. 15r-v.

40 Sutton, 'England's Summons', 9-10.

41 Jackson, London's New-yeeres gift, f. 16v.
} 
idolatry: it 'so exasperated the Judge of the earth, Turkish cruelty hath cut of the goodliest branches of this Vine'. ${ }^{42}$ Thomas Barnes picks a closer and more recently example: 'Foure yeeres agoe the Lord had a wise, and understanding people in the Palatinate, yet the evill which hath since befallen it, was even at that time imminent over it.' 43 In a sermon of 1623 , John Stoughton gives the same point a political edge: whoever sees his 'brother Germans in the faith suffering' and is not sorry for them is a 'sorry Christian'. Religion, he says 'whispers' to the King that 'Defender of that Faith is a more glorious title then Beauclerk' ${ }^{44}$ It is not implausible to suggest that the strength of feeling about the loss of the Palatinate may owe something to such exhortations, at Paul's Cross and elsewhere, that encouraged sympathetic identification with other European Protestants.

Jeremiads are sometimes read as lengthy and unpleasant harangues. But many Paul's Cross Jeremiads are rhetorically polished works that successfully combine vehement affective rhetoric with argument and example. One of the finest examples is Thomas Adams' The gallant's burden, a sermon warning against complacency in religious and civic duties. (The gallants attend plays and 'cannot sitte on their Fathers seates to doe good in the Common-wealth'.) ${ }^{45}$ Preached on 29 March 1612, Adams does not claim that war, plague or famine threaten England (a situation he contrasts starkly with the 'unquiet bread long eaten in the Low-countries', f. 20r). England's danger is a product of its peace, and the preacher's burden is that he must warn against a future calamity that most of his hearers do not believe is imminent. Adams begins by making the preacher's predicament a cause for his auditors' sympathy: the 'Word of the eternall

\footnotetext{
${ }^{42}$ Ley, The bruising of the serpents head, 8.

${ }^{43}$ Barnes, The wise-mans forecast, 11.

${ }^{44}$ Stoughton, Choice sermons, 139-140. On the dating of this sermon and for a detailed discussion of its political context during the controversy over the 'Spanish Match', see Jeanne Shami, 'The Love-sick spouse: John Stoughton's Paul's Cross sermon in context'.

45 Adams, The Gallant's Burden, f. 18r.
} 
God is no lighter a Burden' to Adams and his fellow ministers than it was to the prophets in the Bible, and if the preacher neglect his duty (as some do, Adams admits), then God will load them with 'the Burden of all their sinnes, whose soules have bled to death by our negligence' (ff. $3 \mathrm{v}-4 \mathrm{v}$ ). Adam then exclaims that the sins of the people require sermons of judgement from the preacher burdened with their welfare:

Alasse, how should we sing the songes of Syon to a strange people? The Pulpit (I confesse) should be the Mercie seate; but your sinnes have made it a Tribunall, or Bench of Judgement: Nothing but the thunders of Sinai (and scarce those) can waken vs from our dead sleepe' (f. 6r).

The switch from third to first person plural pronouns is a pronounced feature of Adams' sermon. When castigating individual sins, Adams creates personifications (the gallant, the Atheist, or the papist); when insisting on the duty of repentance, he speaks collectively: in the plural and to the whole city:

Our sinnes are not low, slow, few, or sleightly done; negligence sinnes, security sinnes, contempt sinnes, presumption and hard-heartednes sins. There is the Scorners Chaire, the Drunkardes Bench, the Idle-mans Cushion, the Usurers Studie: Oh where is Repentance, to rowse these? God is angry; we have been smitten, not in the Skirts and Suburbes of our Common-wealth onely, our Citie, Body, and whole unitie hath been pearced to the soule (ff. $24 \mathrm{v}-25 \mathrm{r}$ ).

Addressing England and London's neglect of holiness requires individual action and collective purpose too. The preacher is burdened with denouncing sin, but he appeals to the secular authorities to play their part: 'Fathers and Brethren, helpe', he exclaims, and 'pittie the miscarrying soules, that have no mercy on themselves'. When the preacher's words fail 'let your Hands compell them to the service of God' (f. 28v).

Adams does not harangue his hearers; indeed, the sermon's final exhortation begins on a quiet note that invites its hearer to 'reason \& discuss' the question of repentance. He reserved till now 'to draw your comming with more alacritie' a reminder that forgiveness is promised to all those who repent, even the 'sonnes of the prophanest Esau' (f. 32v) With a vivid exhortation to see Christ 'standing on the Battlementes of 
Heaven', and 'wafting you to him'. Adams draws his sermon to a close. He ends on an intimate note, with Christ is a friend 'more able, more willing, more certaine' than any other (f. 35r). Adams' purpose was to exhort the hearers to repentance by impressing on them the threat of destruction and the promise of salvation, and he speaks as if both options were available to his audience collectively. It would be rhetorically ineffective to suggest that all hope was lost.

To conclude, then, we can say that exhortation became the term used to describe the persuasive function of the sermon, and it was a rhetorically complicated one that required more than the deployment of particular figures of speech. To effect a change in the auditory, the preacher needed to move their will, through the reasonable faculties but also through the movement of the emotions (which should respond to a vehement appeal to the love of God and neighbour). Exhortation required the deployment of powerful arguments that provided the hearers with 'means to and motives for' resolving on a change of life. And most importantly of all, it required sympathy: the preacher had to reach out emotionally to his hearers and demonstrate to them his own faith and trust in God. If he was to reform the city and the Church, the preacher of the Jeremiad had to encourage his hearers to see that their predicament was a common one: the threat of judgement hung over all of them. They needed to sympathise with each other if they were to realize with sufficient urgency the need to change their ways. Style and argument were important strategies, but they had to be accompanied with the communication of conviction, the 'demonstration of the spirit' that was beyond rhetoric. Exhortation reveals the careful attention that sacred rhetoric paid to the emotions, and the nuanced understanding that it offered of the links between thought and feeling in those the preacher addressed. 


\section{Bibliography:}

Adams, Thomas, The Gallant's Burden (1612).

Andrewes, Lancelot, XCVI Sermons, (1629).

Aristotle, Rhetoric, 1356a, trans John Henry Freese, LCL, 193 (Harvard University Press, Loeb Classical Library, 1926).

Augustine, City of God, IX.5, trans David S. Wiesen (Harvard University Press, 1968), LCL 414,

Auksi, Peter, Christian plain style: the evolution of a spiritual ideal (McGill-Queen's University Press, 1995).

Barnes, Thomas, The wise-mans forecast against the evill time (1624)..

Bercovitch, Sacvan, The American Jeremiad (Madison: University of Wisconsin Press, 1978).

Bernard, Richard, The faithful shepheard (1621 ed).

Bremer, Francis, 'To Live Exemplary Lives: Puritans and Puritan Communities as Lofty Lights', The Seventeenth Century, 7 (1992): 27-39.

- - - , and Ellen Rydell, 'Performance Art? Puritans in the pulpit', History Today 45.9 (1995): 50-4.

Cicero, De Oratore, II.lxxxii.337, trans. Sutton and Rackham (Harvard University Press 1942; repr. 1967), LCL, 348.

- - -, Topica, XXII.86, trans. H.M. Hubbell (Harvard University Press 1949; rep. 1993), LCL,386.

Clarke, John, Oratoria Sacra, in Holy oyle for the lampes of the sanctuarie (1630).

Collinson, Patrick, 'The Cohabitation of the Faithful with the Unfaithful', in From Persecution to Toleration: The Glorious Revolution and Religion in England, ed. Ole Peter Grell, Jonathan I. Israel and Nicholas Tyacke (Oxford: Clarendon Press, 1991), 51-76.

Dixon, Thomas, From passions to emotions: The creation of a secular psychological category (Cambridge University Press, 2003).

Erasmus, Ecclesiastes, ed. Frederick J. McGinness, trans James L.P Butrica, Collected Works of Erasmus, vol. 68 (Toronto: University of Toronto Press, 2015). 
Ettenhuber, Katrin, "Tears of passion" and "Inordinate lamentation": complicated grief in Donne and Augustine', in Passions and subjectivity in early modern culture, ed. Brian Cummings and Freya Sierhuis (London: Routledge, 2013), 201-16.

Fenner, William, A treatise of the affections; or the soules pulse (1641).

Foster, Stephen, The Long Argument: English Puritanism and the Shaping of New England Culture, 1570-1700 (Chapel Hill: University of North Carolina Press, 1991).

Gerardus, Andreas, (Hyperius) De formandis concionibus sacris (1553), trans. The practis of preaching ... Written in Latin and now Englished by John Ludham (1577).

Hemmingsen, Niels, Pastor, sive pastoris optimus vivendi agendique modus (1562), trans. The Preacher, or Method of Preaching... translated into English by J[ohn] $H$ [orsfall (1574).

Hunt, Arnold, The art of hearing: English preachers and their audiences, 1590-1640 (Cambridge University Press, 2010).

Jackson, Thomas, London's New-yeeres gift. Or The Uncouching of the foxe (1609).

James, Susan, Passion and action: The emotions in seventeenth-century philosophy (Oxford University Press, 1999).

Keckermann, Barthomew, Rhetoricae Ecclesiasticae (Hanau, 1606).

Kleinhans, Robert G., 'Ecclesiastes sive de Ratione Concionandi', in Essays on the Works of Erasmus, ed. Richard L. DeMolen (Yale University Press, 1978), 253-266.

Kneidel, Greg, 'Arts Praedicandi: Theories and Practice', in The Oxford Handbook of the early modern sermon, ed. Peter McCullough, Hugh Adlington and Emma Rhatigan (Oxford University Press, 2011), 3-20.

Ley, Roger, The bruising of the serpents head (1622).

Lombardo Nicholas E, O.P., The Logic of Desire: Aquinas on Emotion (Washington D.C.: The Catholic University of America Press, 2011).

McGiffert, Michael, 'God's Controversy with Jacobean England', The American Historical Review, 88 (1983): 1151-1174.

Miller, Perry, The New England Mind: The Seventeenth Century (New York: Macmillan, 1939).

Morrissey, Mary, 'The Paul's Cross Jeremiad and Other Sermons of Exhortation', in Paul's Cross and the culture of persuasion in England, 1520-1640, ed. Torrance Kirby (Leiden: Brill, 2014). 
O'Malley, John, 'Erasmus and the History of Sacred Rhetoric: The Ecclesiastes of 1535', Erasmus of Rotterdam Yearbook, 5 (1985): 1-29; repr., O'Malley, Religious culture in the sixteenth century (Hampshire: Variorum, 1993), vii.

Peacham, Henry, The Garden of Eloquence (1593).

Perkins, William, The Arte of Prophecying (1607).

- - , Of the calling of the ministerie, two treatises, in Works, 3 vols (1616-18) vol. III.

Quintilian Institutio Oratoria, IX. ii. 103, trans. Donald A. Russell, The orator's education (Harvard University Press, 2001), LCL 127.

Reynolds, Edward, A treatise of the passions and faculties of the soule of man (1640).

Scaliger, J. C., Poetices libri septem ([Heidelberg], 1594).

Shami, Jeanne, 'The Love-sick spouse: John Stoughton's Paul's Cross sermon in context', in Paul's Cross and the culture of persuasion in England, 1520-1640, ed. Torrance Kirby and P.G. Stanwood (Leiden: Brill, 2014), 389-409.

Shuger, Debora K., Sacred rhetoric: The Christian grand style in the English Renaissance (Princeton University Press, 1988).

- - - , 'The philosophical foundations of sacred rhetoric', in Rhetorical inventions and religious inquiry: New perspectives, ed. Walter Jost and Wendy Olmsted (New Haven: Yale University Press, 2000), 47-64.

Skinner, Quentin, Reason and rhetoric in the philosophy of Hobbes (Cambridge University Press, 1996).

Stoughton, John, Choice sermons preached upon select occasions (1640).

Sutcliffe, Matthew, De recte studii theologici ratione... eidem etiam adjunctus est brevis de concionum ad populum formulis (London, 1602).

Sutton, Thomas, 'England's Summons', in Englands first and second summons (1616).

Ursinus, Zachariah, Methodus formandi concionem, in Keckermann, Rhetoricae Ecclesiasticae (1606).

Van Engen, Abram C., Sympathetic Puritans: Calvinist fellow feeling in early New England (Oxford University Press, 2015)..

Vickers, Brian, In defence of rhetoric (Oxford: Clarendon, 1989).

Wilkins, John, Ecclesiastes (1646).

Wright, Thomas, The passions of the minde in generall (1604). 